\title{
TWO NEW SPECIES OF ACHYROCLINE (ASTERACEAE: INULEAE) \\ FROM MÉXICO
}

\author{
Guy L. Nesom
}

Department of Botany, University of Texas, Austin, Texas 78713 U.S.A.

\begin{abstract}
Two new species of Achyrocline are described from México, A. guerreroana and A. oaxacana. Additional distributional records are reported for A.turneri, including one from Chiapas, México, bringing to five the number of species of Achyrocline in México.

KEY WORDS: Achyrocline, Inuleae, Asteraceae, México.

The taxonomy of Achyrocline in México and Central America has very recently been summarized (Nesom 1990). Since the completion of that paper, however, study of specimens identified as Gnaphalium has uncovered additional and significant distributional records for one of the species treated earlier and brought to light two more previously undescribed species.
\end{abstract}

Achyrocline guerreroana Nesom, spec. nov. TYPE: México. Guerrero: Atoyac/Tlacotepec, $37.9 \mathrm{~km} \mathrm{NE}$ of El Paraiso, $100.8 \mathrm{~km} \mathrm{NE}$ of Atoyac, woods of pine and alder, $2200 \mathrm{~m}, 19 \mathrm{Dec} 1984$, C.P. Cowan 4964 (HOLOTYPE: TEX!; Isotype: MEXU).

Achyrocline turneri Nesom similis foliis anguste elliptici lanceolatis epetiolatis et lobis corollis glandulosis sed vestimento eglanduloso trichomatibus basibus tenuibus, phyllariis opaci-albidis eglandulosis, et corollis ad bases bulbiformibus differt.

Erect herbs. Stems ca. $5 \mathrm{dm}$ tall, densely villous-tomentose with tawny hairs. Leaves narrowly elliptic-lanceolate, $9-11 \mathrm{~cm}$ long, $12-17 \mathrm{~mm}$ wide, relatively even sized upwards, long attenuate at both ends, sessile. not clasping or decurrent, strongly discolorous, the upper surface green and thinly villous, the lower surface densely and persistently villous-tomentose with tawny hairs. Heads in dense apical clusters: phyllaries 9-11, white opaque with acute to obtuse apices, not strongly apiculate, the middle and inner with a lower medial, narrowly elliptic-lanceolate, sparsely villous, eglandular. herbaceous portion. Pistillate flowers $1-3$, filiform, basally inflated. Hermaphroditic flowers 
2-3, narrowly tubular, $3.0 \mathrm{~mm}$ long, bulbous inflated at the base, the lobes minutely sessile glandular. Achenes less than $1 \mathrm{~mm}$ long, glabrous; pappus of numerous, separate. basally caducous bristles.

Known only from the type collection.

Achyrocline guerreroana is similar to A. turneri Nesom in its narrowly elliptic-lanceolate, epetiolate leaves and glandular corolla lobes. but different in its eglandular vestiture of thin based hairs, opaque white, eglandular phyllaries and basally inflated corollas.

Achyrocline oaxacana Nesom, spec. nov. TYPE: México. Oaxaca: Macuiltianguis, pine woods in yellow, sandy soil, $2050 \mathrm{~m}, 13 \mathrm{~J}$ an 1981, $R$. Ortega O. \& M. Ortiz T. 1706 (HOLOTYPE: TEX!).

Achyrocline turneri Nesom similis pubescentia fulva, foliis ellipticis epetiolatis, phyllariis glandulosis fulvis, et corollis glandulosis ad apices sed foliis eglandulosis tomentosis basibus trichomatum filiformibus, et corollis brevioribus differt.

Erect, annual herbs. Stems up to $1 \mathrm{~m}$ tall, densely tomentose, eglandular. Leaves narrowly elliptic-lanceolate to elliptic-oblanceolate, 4-6 cm long, 8-13 $\mathrm{mm}$ wide, gradually attenuate to a sessile base, not clasping or decurrent, eglandular, densely and persistently matted tomentose beneath, glabrescent above with very thin trichomes no thicker at the base than above. Heads in dense, sessile clusters; phyllaries 9, tawny yellowish, hyaline, ovate-lanceolate, slightly apically apiculate, in $2-3$ series of subequal length, the inner $4 \mathrm{~mm}$ long, the middle sessile glandular at the stereome apex. Pistillate flowers 4 . the hermaphroditic (0-)1; corollas narrowly tubular, densely sessile glandular at the apex, the pistillate corollas $2.5 \mathrm{~mm}$ long, the hermaphroditic 2.5-2.8 $\mathrm{mm}$ long, not basally swollen. Achenes ca. $0.5 \mathrm{~mm}$ long, minutely papillate.

Known only from the type collection.

Achyrocline oaxacana is similar to A. turneri in its tawny pubescence, elliptic, epetiolate leaves, yellowish, glandular phyllaries, and gland tipped corollas without a prominently swollen base. It is different in its eglandular leaves with a tomentum of thin based trichomes and shorter corollas. Of 5 dissected heads from the type specimen, 4 had 1 hermaphroditic flower and 4 pistillate ones; one head had no hermaphroditic flowers. Each head had 9 phyllaries.

\section{Achyrocline turneri.}

Since the publication of Achyrocline turneri Nesom, additional records for it have been discovered in a recent loan, all of the specimens previously having been identified as Gnaphalium attenuatum DC. They are cited here because they greatly increase the known range of this species in Guatemala and add México to its distribution. 
Nesom:

Guatemala. Dept. Quiche: San Miguel Uspantan. Apr 1892. Heyde \& Lux 3431 (F); between Los Encuentros and Chichicastenango, 22-23 Dec 1972, Williams. et al. $41680(\mathrm{~F})$. Dept. Solola: Volcán San Pedro, above village of San Pedro, 7 Jun 1942, Steyermark 47186 (F). Dept. Solola/Chimaltenango: near Río Molino. 21 Dec 1972, Williams, et al. 41555 (F). Dept. Alta Verapaz: vicinity of San Juan Chamelco, Feb 1969, Wilson 41033 (F).

México. Chiapas: Cascada, Siltepec, 1600 m. 3 Mar 1945, Matuda 5078 $(\mathrm{F})$.

There are now five species of Achyrocline known from México and Central America: A. deflexa Robinson \& Greenm., A. turneri, A. guerreroana, A. oaxacana and $A$. ventosa Klatt. The last three are known only from México.

\section{ACKNOWLEDGMENTS}

I thank Billie Turner and Michael Dillon for their review of the manuscript and the staff at $\mathrm{F}$ for a loan of specimens.

\section{LITERATURE CITED}

Nesom, G.L. 1990. Taxonomy of Achyrocline (Asteraceae: Inuleae) in México and Central America. Phytologia 68:181-185. 


\section{$2 \mathrm{BHL}$ Biodiversity Heritage Library}

Nesom, G L. 1990. "Two new species of Achyrocline (Asteraceae: Inuleae) from México." Phytologia 68, 363-365. https://doi.org/10.5962/bhl.part.11919.

View This Item Online: https://www.biodiversitylibrary.org/item/47153

DOI: https://doi.org/10.5962/bhl.part.11919

Permalink: https://www.biodiversitylibrary.org/partpdf/11919

\section{Holding Institution}

New York Botanical Garden, LuEsther T. Mertz Library

\section{Sponsored by}

The LuEsther T Mertz Library, the New York Botanical Garden

\section{Copyright \& Reuse}

Copyright Status: In copyright. Digitized with the permission of the rights holder.

Rights Holder: Phytologia

License: http://creativecommons.org/licenses/by-nc-sa/3.0/

Rights: https://biodiversitylibrary.org/permissions

This document was created from content at the Biodiversity Heritage Library, the world's largest open access digital library for biodiversity literature and archives. Visit BHL at https://www.biodiversitylibrary.org. 